\title{
PERAN ORANG TUA DALAM PENDIDIKAN ANAK USIA DINI
}

\section{Ahmad Tarmizi dan Sulastri}

Dosen Tetap FITK UIN Sultan Thoha Syaifuddin, Jambi

dan

Dosen Fakultas Ilmu Tarbiyah dan Keguruan UIN Raden Fatah

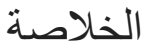

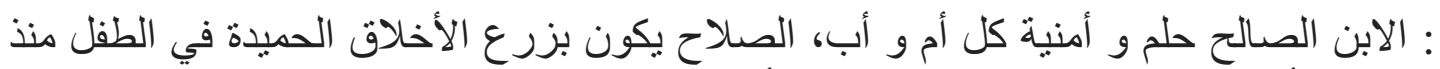

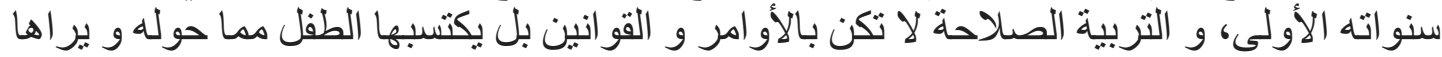

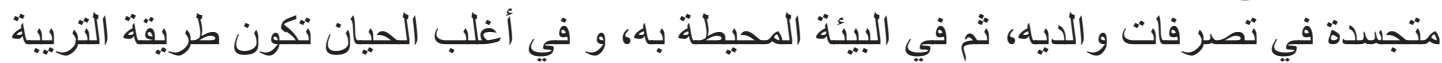

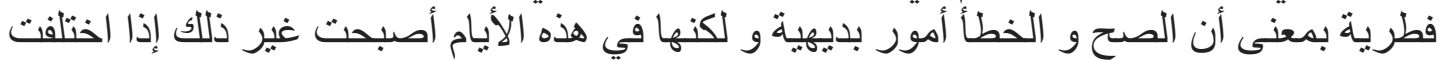

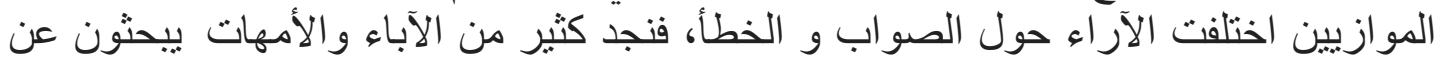

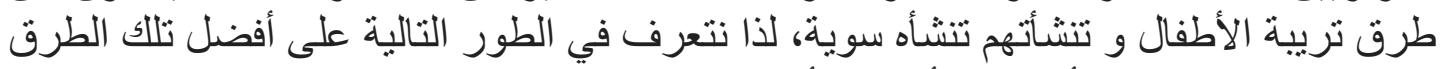

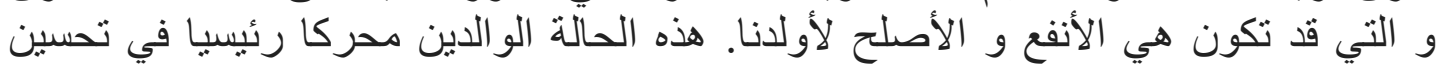
إمكانات الأطفال وسيلة لتحفيز وتقديم التسهيلات المختلفة التي تحتاج إليها.

$$
\text { كلمات البحث : دور الآباء والأمهات، في مرحلة الطفولة المبكرة }
$$

\section{Pendahuluan}

Islam sangat memperhatikan kehidupan manusia sejak dini. Dimulai dari fase kandungan sampai pada kedewasaan. Sehingga seorang ibu yang sedang hamil diperbolehkan untuk membatalkan puasanya, jika dihawatirkan dapat membahayakan janin atau anak yang sedang dikandung atau disusuinya. Semua itu membuktikan bahwa Islam sangat menghargai kehidupan manusia.

Dalam pandangan Islam pendidikan harus diberikan semenjak dalam kandungan. Karena pendidikan yang dilakukan sejak dini memiliki keberhasilan yang sangat tinggi dalam menentukan tumbuh kembang karakter anak selanjutnya. Oleh karen itu peranan kedua orang tua (suami dan isteri) sangat besar dalam pendidikan anak yang dimulai dari dalam kandungan.

Hubungan kasih sayang suami isteri yang mengikat mereka berdua tetap bersama dan dari kasih sayang inilah terlahir ketenteraman hati, ketenangan pikiran, kebahagiaan jiwa, dan kesenangan jasmaniah. Dengan kasih sayang ini juga dapat memperkuat rasa kebersamaan antar anggota keluarga, kekokohan pondasi 
keluarga, dan menjaga keutuhannya. Firman Allah dalam Al Quran surah Arrum ayat 21 yang berbunyi:

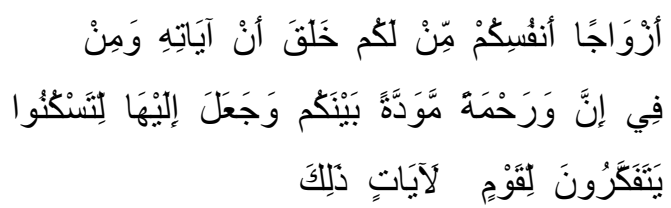

Artiya: Dan di antara tanda-tanda kekuasaan-Nya ialah Dia menciptakan untukmu istri-istri dari jenismu sendiri, supaya kamu cenderung dan merasa tenteram kepadanya, dan dijadikan-Nya di antaramu rasa kasih dan sayang. Sesungguhnya pada yang demikian itu benar-benar terdapat tanda-tanda bagi kaum yang berpikir.(QS. Ar Ruum:21).

Cinta dan kasih sayang dapat menciptakan rasa saling menghormati dan saling bekerja sama, bahu-membahu dalam menyelesaikan setiap problem yang datang menghadang dalam perjalanan kehidupan suami isteri, sehingga ia sangat berperan dalam menciptakan keseimbangan mental anak. Rumah tangga ibarat sebuah perahu seorang suami adalah nahkodanya sedangkan isteri sebagai penumpang yang bersedia di bawa berlayar kemanapun oleh nahkodanya. Maka tak terelakkan dalam pelayaran tersebut akan di temui gelombang, angin kencang bahkan badaipun akan datang, maka dengan cinta kasih, keharmonisan dan kebersamaan akan membuat kapal tersebut selamat sampai ketepian. Karena itulah sebuah pernikahan bukanlah tujuan tapi ia adalah awal dari perjuangan bersama antara suami dan isteri.

Suami isteri harus terus menjaga dan memperkuat tali kasih di antara mereka berdua, baik sebelum masa kelahiran anak mereka maupun setelahnya. Memperkuat rasa cinta dan kasih sayang merupakan kewajiban yang diperintahkan oleh Allah SWT. Karena itu, menjaga keutuhan kasih sayang termasuk dalam perintah Allah dan merupakan salah satu cara mendekatkan diri kepada sang khalik.

Memelihara keharmonisan dan kehangatan bagi pasangan suami dan isteri juga berperan penting untuk mewujudkan kebahagiaan dan keseimbangan mental dan psikolois anak. Banyak terlihat di masyarakat kita tentang kasus anak yang tumbuh menjadi pribadi terganggu secara psikologis akibat keretakan hubungan atau bahkan perceraian orang tuanya. Bila setiap hari sang anak hanya disugukan dengan pertengkaran dan perselisihan orangtua tentunya hal itu akan tertanam dalam diri anak dan 
menjadi contoh bagi anak kedepannya, wajar jika di masa mendatang anak akan cenderung mudah melakukan pertengkaran dan perselisihan.

Menjaga hubungan kedekatan dan kehangatan orang tua dan anak merupakan modal yang sangat penting bagi anak dalam menapaki masa depannya. Karena dengan kedekatan anak dan orang tuanya dapat menciptakan kelancaran komunikasi antara keduanya. Maka, tatkala seorang anak menghadapi problem dan kendala dalam hidupnya, orang tua dapat berdiri di dekat anak selayaknya seorang sahabat sejati, Sehingga tidak akan ada rahasia antara anak dan orangtua. Bahkan anak akan merasa aman dan nyaman yang ahirnya akan melahirkan sifat positif.

\section{Perkembangan Anak Usia Dini}

Seorang anak terlahir dalam keadaan fitrah, artinya seorang anak terlahir dalam keadaan bersih laksana kertas putih yng belum dituliskan apapun di atasnya. Akan tetapi seorang anak memiliki potensi yang sangat luar biasa jika mampu menggalinya. Maka jika orangtuanya mampu mengeluarkan mutiara dari dalam diri anak tersebut maka ia akan bersinar terang benderang. Rasulullah Shallallaahu alaihi wa Salam bersabda:
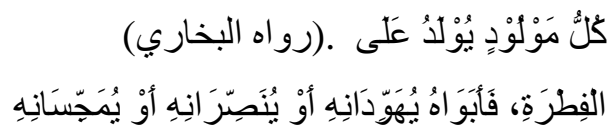

Artinya: "Setiap anak dilahirkan dalam keadaan fitrah (Islam), maka orang tuanya yang menyebabkan dia menjadi Yahudi, Nasrani atau Majusi.” (HR. Al-Bukhari).

Menurt Ahmad Tafsir (2008:35) Fitrah yang di maksud dalam hadits di atas adalah potensi. Potensi adalah kemampuan; jadi fitrah yang dimaksud adalah pembawaan. Ayah-ibu dalam hadits ini adalah lingkungan sebagaimana yang di maksud oleh para ahli pendidikan. Kedua-duanya itulah, menurut hadits ini yang menentukan perkembangan seseorang.

Pendidikan anak hendaknya dimulai sejak dini sebagai usaha membantu anak agar fitrah yang disebut dengan kecakapan/ability baik fisik maupun non fisik (Nana Syaodih 2004:92) itu agar dapat berkembang secara maksimal sesuai dengan ketentuan dalam syari'at Islam. Karena salah satu misi kependidikan pertama Nabi SAW adalah menanamkan aqidah yang benar, yaitu aqidah tauhid, memahami seluruh fenomena alam dan kemanusiaan sebagai suatu kesatuan, suatu yang 
holistik. Dalam kerangka tauhid, SDM

adalah manusia yang memiliki kualitas yang seimbang: beriman, berilmu, dan beramal; cakap lahir dan batin; berkualitas secara emosional, rasional, dan sosial/memiliki EQ, IQ, dan SQ yang tinggi (Azyumardi Azra, 1990:55-56).

Berdasarkan Undang-undang Nomor 20 tahun 2003 tentang Sistem Pendidikan Nasional yang dimaksud Anak Usia Dini adalah kelompok manusia yang berusia 0-6 tahun (Depdiknas, 2002:3-4). Anak usia dini adalah kelompok anak yang berada dalam proses pertumbuhan dan perkembangan yang bersifat unik, dalam arti memiliki pola pertumbuhan dan perkembangan (koordinasi motorik halus dan kasar), intelegensi (daya pikir, daya cipta, kecerdasan emosi, dan kecerdasan spiritual), sosial emosional (sikap dan prilaku serta agama), bahasa dan komunikasi yang khusus sesuai dengan tingkat pertumbuhan dan perkembangan anak.

Perkembangan anak usia dini sebenarnya dimulai Sejak pranatal. Usia dini merupakan usia yang sangat penting bagi perkembangan anak sehingga disebut golden age. Pada saat itu, perkembangan otak sebagai pusat kecerdasan terjadi sangat pesat. Setelah lahir, sel-sel otak mengalami mielinasi dan membentuk jalinan yang kompleks, sehingga nantinya anak bisa berpikir logis dan rasional. Selain otak, organ sensoris seperti pendengar, penglihatan, penciuman, pengecap, perabaan, dan organ keseimbangan juga berkembang pesat (Gardner, 1993:23).

Hasenstab dan Horner (1982:122) mengatakan bahwa pendidikan anak usia dini dimulai tiga tahun sampai dengan enam tahun yang sering dikatakan sebagai pendidikan prasekolah, dan pada masa ini anak mengalami perkembangan yang sangat pesat baik fisik, maupun psikis atau kejiwaan. Sehingga pembelajaran pada masa ini bagaikan mengukir di atas batu "at ta'allumu fi al sighari ka al naqshi 'ala al hajari".

Berdasarkan keunikan dalam pertumbuhan dan perkembangannya, anak usia dini terbagi dalam empat tahapan, yaitu: (a) masa bayi lahir sampai 12 bulan, (b) masa balita usia 1-3 tahun, (c) masa prasekolah usia 3-6 tahun, (d) masa kelas awal SD 6-8 tahun. Pertumbuhan dan perkembangan anak usia dini perlu diarahkan pada peletakan dasar-dasar 
yang tepat bagi pertumbuhan dan perkembangan manusia seutuhnya, yaitu pertumbuhan dan perkembangan fisik, daya pikir, daya cipta, sosial emosional, bahasa dan komunikasi yang seimbang sebagai dasar pembentukan pribadi yang utuh.

Berbagai hasil penelitian menunjukkan bahwa ada hubungan yang sangat kuat antara perkembangan yang dialami anak pada usia dini dengan keberhasilan mereka dalam kehidupan selanjutnya. Misalnya, anak-anak yang hidup dalam lingkungan (baik di rumah maupun di $\mathrm{KB}$ atau TK) yang kaya interaksi dengan menggunakan bahasa yang baik dan benar akan terbiasa mendengarkan dan mengucapkan kata-kata dengan benar, sehingga ketika mereka masuk sekolah, sudah mempunyai modal untuk membaca (http://www.whitehouse.gov/infocus/e arlychild-hood/sect 2.html).

Aspek-aspek perkembangan anak usia dini meliputi:

1. Aspek Perkembangan Kognitif

Pertumbuhan dan perkembangan manusia berarti perubahan dalam struktur dan fungsi ciri-ciri manusia. Perubahan-perubahan itu terjadi dalam kemajuan terus menerus dalam tahap-tahap yang disebut proses kematangan. Dalam Al Quran surah Al Mukminun ayat 12-14 Allah SWT. menjelaskan asal mula penciptaan manusia.

Artinya: "Dan sesungguhnya Kami telah menciptakan manusia itu dari suatu saripati (berasal) dari tanah. Kemudian Kami jadikan saripati itu air mani (yang disimpan) dalam tempat yang kokoh (rahim). Kemudian air mani itu Kami jadikan segumpal darah, lalu segumpal darah itu kami jadikan segumpal daging, dan segumpal daging itu Kami jadikan tulang belulang, lalu tulang belulang itu Kami bungkus dengan daging. Kemudian Kami jadikan ia makhluk yang (berbentuk) lain. Maka Maha Sucilah Allah, Pencipta Yang Paling Baik.” (QS. Al Mu'minuun (23): 12-14).

Dari makna ayat diatas jelas Al Quran telah mengungkap asal mula kejadian manusia. Barulah pada abad ke 15 silam para ahli biologi meneliti tentang organ tubuh manusia yang berasal dari "saripati tanah" sebagai substansi dasar kehidupan manusia adalah protein, sari-sari makanan yang kita makan berasal dan hidup dari tanah. Dengan adanya proses 
metabolise dalam tubuh yang diantaranya menghasilkan sperma (laki-laki) dan ovum (sel telur wanita) dalam rahim, kemudian berproses ke pembentukan manusia seperti yang di jelskan dalam ayat tedahulu (Shihab:2002).

Piaget (Sumantri, dkk. 2009:1-15) mengemukakan bahwa proses perkembangan kognitif anak dari kecil hingga dewasa melalui empat tahap perkembangan, yaitu:

a. Tahap Sensori Motor (0-2 Tahun)

Pada tahap ini, kegiatan intelektual anak hampir seluruhnya merupakan gejala yang diterima secara langsung melalui indera. Pada saat anak mencapai kematangan dan secara perlahan mulai memperoleh keterampilan berbahasa, mereka menerapkannya pada objek-objek yang nyata. Pada tahap ini anak mulai memahami hubungan antara benda dengan nama benda tersebut.

b. Tahap Praoperasional (2-7 Tahun)

Perkembangan yang pesat dialami oleh anak pada tahap ini. Anak semakin memahami lambang-lambang bahasa yang digunakan untuk menunjukkan benda-benda. Keputusan yang diambil hanya berdasarkan

intuisi, bukan atas dasar analisis rasional. Kesimpulan yang diambil merupakan kesimpulan dari sebagian kecil yang diketahuinya, dari suatu keseluruhan yang besar. Anak akan berpendapat bahwa pesawat terbang berukuran kecil karena itulah yang mereka lihat di langit ketika ada pesawat terbang yang lewat.

c. Tahap Operasional Konkret (7-11 Tahun)

Pada tahap ini anak mulai berpikir logis dan sistematis untuk mencapai pemecahan masalah. Masalah yang dihadapi dalam tahap ini bersifat konkret. Anak akan merasa kesulitan bila menghadapi masalah yang bersifat abstrak. Pada tahap ini anak menyukai soal-soal yang telah tersedia jawabannya.

d. Tahap Operasional Formal (11-15 Tahun)

Anak mencapai tahap perkembangan ini ditandai dengan pola pikir seperti orang dewasa. Anak telah dapat menerapkan cara berpikir terhadap permasalahan yang konkret maupun abstrak. Pada tahap ini anak sudah dapat membentuk ide-ide dan berpikir tentang masa depan secara realistis.

Menurut Hasan Langgulung 
(1992:267-268) pandangan teori Jean Piaget terhadap perkembangan kognitif anak dari semenjak lahir sampai dewasa dapat disimpulkan bahwa ada tiga proses pokok yang terlibat ketika kanak- kanak berreaksi atau mengintegrasikan pengalaman kedalam operasi mental.

Pertama ada assimilasi, yaitu menggabungkan pengalaman baru kedalam garis-garis besar atau pola-pola yang ada.

Kedua akomodasi, yaitu dimana struktur mental yang ada sebagai respon terhadap lngkungn yang berubah.

Ketiga proses paling penting yang mempengaruhi pertumbuhan kognitif adalah keseimbangan (eguilibration), dimanna kanak-kanak mencapa keseimbangan antara hal yang dulunya sudah di fahami dan kemasukan (input) yang baru.

\section{Aspek Perkembangan Fisik}

Masa kanak-kanak awal berlangsung dari dua sampai enam tahun, oleh para pendidik dinamakan sebagai usia pra-sekolah. Pada awal masa anak-anak dianggap sebagai saat belajar untuk mencapai berbagai ketrampilan karena anak senang mengulang dan senang mencoba hal-hal baru. Awal masa anak-anak ditandai oleh moralitas dengan paksaan, suatu masa dimana anak belajar mematuhi peraturan secara otomatis melalui hukuman dan pujian. Periode ini juga masa penegakan disiplin dengan cara yang berbeda, ada yang dikenakan disiplin otoriter, lemah dan demokratis. Ciri khas yang dimiliki fase ini adalah perkembangan dipusatkan untuk menjadi manusia social (belajar bergaul dengan orang lain).

Rasulullah SAW. telah menjelaskan dalam sebuah hadits bahwa pada masa ini orangtua sudah bisa memulai menanamkan kedisiplinan kepada anak-anak dengan mengajar dan memerintahkan mereka untuk mengerjakan solat. Bahkan apabila umurnya sudah 10 tahun, seorang ayah boleh memukul anaknya jika enggan mengerjakan solat. Rasulullah SAW telah bersabda:

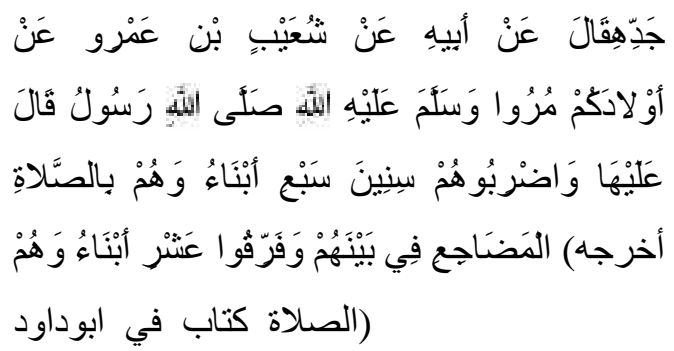

Artinya: "Dari 'Amar bin Syu'aib, dari ayahnya dari kakeknya ra., ia berkata: Rasulullah saw. Bersabda: "perintahlah anak-anakmu mengerjakan salat ketika berusia tujuh 
tahun, dan pukullah mereka karena meninggalkan salat bila berumur sepuluh tahun, dan pisahlah tempat tidur mereka (laki-laki dan perempuan)!" (HR. Abu Daud dalam kitab sholat).

Perkembangan

merupakan

perkembangan

pengendalian gerakan jasmaniah

melalui kegiatan pusat syaraf, urat syaraf dan otot terkoordinasi (Hurlock: 1998). Keterampilan motorik anak terdiri atas keterampilan motorik kasar dan keterampilan motorik halus. Keterampilan motorik anak usia 4-5 tahun lebih banyak berkembang pada motorik kasar, setelah usia 5 tahun baru terjadi perkembangan motorik halus.

Pada usia 4 tahun anak-anak masih suka jenis gerakan sederhana seperti berjingkrak-jingkrak, melompat, dan berlari kesana kemari, hanya demi kegiatan itu sendiri tapi mereka sudah berani mengambil resiko. Walaupun mereka sudah dapat memanjat tangga dengan satu kaki pada setiap tiang anak tangga untuk beberapa lama, mereka baru saja mulai dapat turun dengan cara yang sama.

Pada usia 5 tahun, anak-anak bahkan lebih berani mengambil resiko dibandingkan ketika mereka berusia 4 tahun. Mereka lebih percaya diri melakukan ketangkasan yang mengerikan seperti memanjat suatu obyek, berlari kencang dan suka berlomba dengan teman sebayanya bahkan orangtuanya (Santrock,1995: 225).

3. Aspek Perkembangan Bahasa

Potensi berbahasa merupakan suatu keampuan yang dimiliki semua manusia yang diperoleh tanpa melalui pembelajaran khusus. Serta waktu yang diperlukan relatif singkat, sehingga tanpa disadari seorang anak sudah dapat berkomunikasi dengan orang-orang di sekitarnya dalam berbagai keperluan apapun. Namun pada kenyataannya semua itu tidaklah secara tiba-tiba atau sekaligus, tetapi bertahap seiring dengan perkembangaan fisik, mental, intelektual dan sosialnya.

Menurut Johan Amos Comenius dalam Kartini Kartono (2007: 34-35) berpendapat bahwa perkembangan bahasa seseorang terdiri dari empat periode perkembangan, yaitu:

a. Periode Sekolah-Ibu (0-6 Tahun)

Pada periode ini hampir semua usaha bimbingan-pendidikan berlangsung di lingkungan keluarga, 
terutama aktivitas ibu sangat mempengaruhi proses perkembangan anak. Hart \& Risley (Morrow, 1993) mengatakan umur 2 tahun, anak-anak memproduksi rata-rata dari 338 ucapan yang dapat dimengerti dalam setiap jam, cakupan lebih luas adalah antara rentangan 42 sampai 672. 2 tahun lebih tua anak-anak dapat mengunakan kira-kira 134 kata-kata pada jam yang berbeda, dengan rentangan 18 untuk 286.Oleh karena itu, perkembangan bahasa anak ditandai oleh keseimbangan dinamis atau suatu rangkaian kesatuan yang bergerak dari bunyi-bunyi atau ucapan yang sederhana menuju tututran yang lebih kompleks.

b. Periode Sekolah-Bahasa-Ibu (6-12 Tahun)

Pada periode ini anak baru mampu menghayati setiap pengalaman dengan pengertian bahasa sendiri (bahasa ibu). Bahasa ibu ini digunakan untuk berkomunikasi dengan orang lain, yaitu untuk mendapatkan impresi dari luar berupa pengaruh, sugesti serta transmisi kultural dari orang dewasa, dan untuk mengekspresikan kehidupan batinnya kepada orang lain.
c. Periode Sekolah-Latin (12-18 Tahun)

Pada periode ini anak mulai diajarkan bahasa latin sebagai bahasa kebudayaan. Bahasa ini perlu diajarkan kepada anak agar anak mencapai taraf beradab dan berbudaya.

d. Periode Sekolah-Universitas (18-24 Tahun)

Pada periode yang terakhir ini anak muda mengalami proses pembudayaan dengan menghayati nilai-nilai ilmiah, di samping mempelajari macam-macam ilmu pengetahuan.

Manurut Conny R. Semiawan (2000: 128-136) tahap perkembangan bahasa anak terdiri dari empat tahap, yaitu:

a. Perkembangan Bahasa Usia Bayi
Secara umum bayi mulai mengeluarkan ucapan pada saat usianya 10-16 bulan, walaupun pada kenyataannya ada juga yang memerlukan waktu lebih lama dari itu. Sebelum anak-anak mengucapkan kata-kata, terlebih dahulu membuat ocehan misalnya dengan ucapan baa, maa atau paa. Mengoceh ini mulai terjadi saat usia sekitar 3-6 bulan. Tujuan komunikasi yang dilakukan oleh bayi pada usia dini ialah untuk menarik perhatian orang tua dan orang 
lain yang ada di sekitarnya. Pada umumnya, bayi menarik perhatian orang lain dengan membuat kontak mata, membunyikan ucapan, serta menggerak-gerakkan tangan.

Biasanya kata-kata anak yang pertama kali muncul adalah nama-nama orang penting yang ada disekitarnya, nama-nama binatang, dan benda-benda lain yang ada di sekitarnya. Anak-anak yang telah memasuki usia 18-24 bulan mulai mengucapkan pernyataan dengan dua kata.

b. Perkembangan Bahasa Anak Usia Dini

Beberapa anak usia pra sekolah memiliki kesulitan dalam mengucapkan kelompok konsonan, misalnya untuk mengucapkan kata setrika, mangga, dan lain-lain. Pada usia ini, anak-anak sudah dapat mengembangkan ungkapannya lebih dari dua kata-kata setiap kalimatnya. Anak-anak mulai berbicara dengan urutan kata yang menunjukkan suatu pendalaman yang meningkat terhadap aturan yang komplek tentang urutan kata-kata yang diucapkan. Pada usia ini anak-anak juga sudah mulai mampu mengembangkan pengetahuan tentang makna dengan cepat. c. Perkembangan Bahasa Usia Sekolah

Pada tahap ini penekanan perkembangan berubah dari bentuk bahasa ke isi dan penggunaan bahasa. Anak-anak telah mencapai tahap kreatif dalam perkembangan bahasa. Bahasa kreatif anak dapat didengar dalam bentuk nyanyian atau sajak.

d. Perkembangan Membaca dan Menulis

Salah satu faktor yang berpengaruh pada perkembangan membaca anak usia dini ialah kesediaan orang tua untuk menyediakan bahan bacaan dan menciptakan suasana yang kondusif bagi perkembangan kemampuan membaca anak. Kegiatan membaca yang dilakukan secara alamiah dalam suasana kehidupan sosial memiliki efektifitas yang tinggi untuk peningkatan kemampuan membaca pada anak. Anak usia tujuh atau delapan tahun telah memperoleh pengetahuan tentang huruf, suku kata dan kata. Siswa kelas tiga dan empat sudah mampu menganalisis kata-kata baru dengan menggunakan pola orthograpik dan inferensi kontekstual. Siswa kelas lima dan enam sudah 
mulai membaca dari keterampilan decoding menuju ke pemahaman.

\section{Aspek}

Perkembangan

Sosio-Emosional

Pada fase anak-anak yang dimulai dari usia sebulan sampai usia sekitar tujuh tahun. Pertumbuhan potensi-potensi indera dan psikologis, seperti pendengaran, penglihatan, dan hati nurani sudah sangatlah sempurna, maka seorang anak sudah mulai memiliki rasa suka atau marah terhadap sesuatu, rasa ingin tau yang sangat besar dan keinginan untuk bersosialisasi dengan sesama teman sebaya lainnya. Pola perilaku sosial yang terlihat pada masa kanak-kanak awal, yaitu: kerjasama, persaingan, kemurahan hati, hasrat akan penerimaan sosial, simpati, empati, ketergantungan, sikap ramah, sikap tidak mementingkan diri sendiri, meniru, perilaku kelekatan. Firman Allah dalam surat Al-Nahl ayat 78 yang menjelaskan bahwa manusia telah diberi bekal oleh Allah SWT. Panca indera semenjak manusia dilahirkan.

Artinya:

"Dan

Allah

mengeluarkan kamu dari perut ibumu dalam keadaan tidak mengetahui sesuatupun, dan Dia memberi kamu pendengaran, penglihatan dan hati, agar kamu bersyukur".(QS.Al-Nahl:78).

Dari ayat di atas jelas bahwa dengan bekal tersebut setiap orangtua dapat mempersiapkan diri anak dengan cara membiasakan dan melatih hidup yang baik. Seperti dalam berbicara, makan, bergaul, penyesuaian diri dengan lingkungan, dan berperilaku. Pembiasaan ini terutama pada aspek-aspek afektif (al-infi'ali), sebab jika aspek ini tidak dibiasakan sedini mungkin maka ketika masa dewasanya akan sulit dilakukan. Begitu juga pengenalan aspek-aspek doktrinal agama, terutama yang berkaitan dengan keimanan.

Menurut Erik Erikson (1950) dalam Papalia dan Old, (2008:370) seorang ahli psikoanalisis mengidentifikasi perkembangan sosial anak dengan beberapa tahapan yaitu:

Pertama, tahap Basic Trust vs Mistrust (percaya vs curiga), usia 0-2 tahun. Pada tahap ini bila anak merespon rangsangan, maka ia akan mendapatpengalaman yang menyenangkan dan akan tumbuh rasa percaya diri, sebaliknya pengalaman 
yang kurang menyenangkan akan menimbulkan rasa curiga.

Kedua, tahap Autonomy vs Shame \& Doubt (mandiri vs ragu), usia 2-3 tahun. Pada masa ini anak sudah mampu menguasai kegiatan meregang atau melemaskan seluruh otot-otot tubuhnya. Maka jika masa ini anak sudah merasa mampu menguasai anggota tubuhnya dapat meimbulkan rasa otonomi, sebaliknya bila lingkungan tidak memberi kepercayaan atau terlalu banyak bertindak maka akan menimbulkan rasa malu dan ragu-ragu.

Ketiga, tahap Initiative vs Guilt (berinisiatif vs bersalah), usia 4-5 tahun. Pada masa ini anak akan menunjukkan sikap mulai lepas dari ikatan orang tua, anak dapat bergerak bebas dan berinteraksi dengan lingkungannya. Kondisi lepas dari orang tua menimbulkan rasa untuk berinisiatif, sebaliknya dapat menimbulkan rasa bersalah.

Keempat, tahap Industry vs Inferiority (percaya diri vs rasa rendah diri), usia 6 tahun-pubertas. Pada masa ini anak telah memasuki masa dewasa, sehingga ia sudah dapat melaksanakan tugas-tugasnya sendiri. Dan memerlukan suatu keterampilan tertentu. Bila anak mampu menguasai suatu keterampilan tertentu dapat menimbulkan rasa berhasil, sebaliknya bila tidak menguasai, menimbulkan rasa rendah diri.

Peranan Orangtua dalam Perkembangan Anak Usia Dini

Syariat Islam dengan gamblang menjelaskan peranan orang tua terhadap anaknya mulai dari penunaian kewajiban sampai hak perawatan dan pemeliharaan (al hadanah), sejak dalam kandungan sampai menjelang dewasa. Hadanah artinya memberikan pemeliharaan secara menyeluruh, baik dari segi kesehatan fisik, mental, sosial, maupun dari segi pendidikan dan perkembangannya.

Guna memenuhi kewajiban dan hak tersebut maka setiap orang tua memiliki peranan masing-masing dalam keluarga, sehingga ketika ibu dan ayah merasakan dukungan dari satu sama lain, kompetensi keduanya sebagai orang tua akan tumbuh, dan interaksi dengan anak menjadi lebih efektif. Hal tersebut juga dapat dijadikan indikator kepuasan dalam pernikahan yaitu adanya kesepakatan 
orang tua mengenai pengaturan peran mereka.

a. Peranan seorang suami

Ayah sebagai suami dari istri dan anak-anak, berperan sebagai pencari nafkah, pendidik, pelindung, dan pemberi rasa aman, sebagai kepala keluarga, sebagai anggota dari kelompok sosialnya serta sebagai anggota masyarakat dari lingkungannya. Kewajiban memberikan nafkah yang halal sangatlah dituntut dalam Islam karena semua itu akan mempengaruhi perkembangan prilaku dan akhlak seorang anak nantinya. Dalam Al Quran dijelaskan pada surah Al Baqarah ayat 233 dan Ath Thalaq ayat 7.

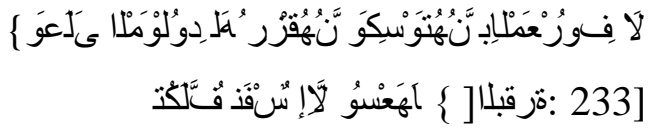

Artinya: "Dan kewajiban ayah memberi makan dan pakaian kepada para ibu dengan cara yang makruf. Seseorang tidak dibebani melainkan menurut kadar kesanggupannya." QS. Al Baqarah: 233.

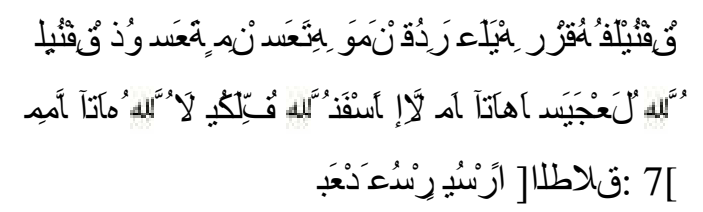

Artinya:"Hendaklah orang yang mampu memberi nafkah menurut kemampuannya. Dan orang yang disempitkan rezekinya hendaklah memberi nafkah dari harta yang diberikan Allah kepadanya. Allah tidak memikulkan beban kepada seseorang melainkan (sekedar) apa yang Allah berikan kepadanya. Allah kelak akan memberikan kelapangan sesudah kesempitan.” QS. Ath Thalaq: 7.

Bagitupun dalam hadits yang diriwayatkan oleh imam Ahmad dan Muslim dijelaskan bahwa pemberian nafkah kepada keluarga sangat besar pahalanya.

Dari abu hurairah, ia berkata: rasulullah saw. bersabda, "sedinar engkau infakkan dijalan Allah, sedinar engkau infakkan dalam (membebaskan hamba, sedinar yang engkau sedekahkan kepada orang miskin dan sedinar yang engkau infakkan kepada keluarga, maka yang lebih besar pahalanya adalah yang engkau infakkan kepada keluargamu”. (HR. Ahmad dan Muslim).(Syekh Faishal, 2005:2462).

Selain memberi nafkah yang halal, selaku orangtua yang bertanggung jawab terhadap anak-anaknya, maka setiap orangtua harus meninggalkan generasi yang kuat. Allah Subhannahu wa Ta'ala berfirman:

Artinya: "Dan hendaklah takut kepada Allah orang-orang yang sekiranya meninggalkan di belakang mereka anak-anak yang lemah, yang mereka khawatir terhadap (kesejahteraan)mereka” (An Nisa: 9).

Pengertian lemah dalam ayat ini adalah lemah iman, lemah fisik, lemah 
intelektual dan lemah ekonomi. Pengabaian salah satu dari empat hal ini adalah ketimpangan yang dapat menyebabkan ketidak seimbangan pada anak. Imam Ibnu Katsir dalam mengomentari pengertian lemah pada ayat ini memfokuskan pada masalah ekonomi. Beliau mengatakan selaku orang tua hendaknya tidak meninggalkan keadaan anak-anak mereka dalam keadaan miskin.

\section{Peranan Seorang Isteri}

Seorang ibu selain sebagai istri dan ibu dari anak-anaknya, ia juga berperan untuk mengurus rumah tangga, sebagai pengasuh dan pendidik anak-anaknya, pelindung, dan sebagai salah satu kelompok dari peranan sosialnya serta sebagai anggota masyarakat dari lingkungannya, di samping itu juga ibu dapat berperan sebagai pencari nafkah tambahan dalam keluarganya.

Memilih istri yang shalehah menjadi tolak ukur keshalehan generasi penerus keluarga, karena ia akan menjadi penentu dalam mendidik anak-anakya kelak. Maka tak terelakkan jika peranan ibu sangat penting dalam kehidupan seorang anak karena segala tindak tanduk seorang ibu dapat direkam oleh anak-anaknya semenjak dari dalam kandungan, baik itu perbuatan, perkataan, maupun gerak gerik lainnya dapat dirasakan oleh seorang anak. Contohnya jika sang ibu lagi bersedih maka janin di dalam kandungan akan merasa gelisah tak menentu karena anak dapat mendengar bunyi apapun diluar dirinya termasuk ia akan mengenali suara ibu dan ayahnya.

\section{Peranan Seorang Anak}

Anak sebagai pelaksana peranan sesuai dengan tingkat perkembangannya baik fisik, mental, sosial, dan spiritual. Pada masa ini Anak diibaratkan sebuah tanaman yang tumbuh, sehingga peran orang tua adalah sebagai tukang kebun, dan sekolah merupakan rumah kaca, dimana anak tumbuh dan matang sesuai pertumbuhannya yang wajar dengan pola asuh yang di berikan setiap orang tua. Sebagai tukang kebun orangtua berkewajiban untuk menyirami, memupuk, merawat, dan memelihara terhadap tanaman yang ada dalam kebun tersebut. Dapat dikatakan bahwa apa yang akan terjadi pada anak tergantung pada 
pertumbuhan secara wajar dan lingkungan yang memberi perawatan.

Allah dalam firman-Nya telah menjelaskan bahwa mendidik dan mengajar anak menjadi kebutuhan pokok dan suatu kewajiban bagi orang tua. Untuk itu Islam menutut bagi setiap orangtua harus memberikan bekal dengan pendidikan (khususnya pengajaran agama) yang terbaik untuk anak-anaknya. Firman Allah dalam surat At Tahrim yang berbunyi:

Artinya: "Hai orang-orang yang beriman, peliharalah dirimu dan keluargamu dari api neraka yang bahan bakarnya adalah manusia dan batu; penjaganya malaikat-malaikat yang kasar, keras, dan tidak mendurhakai Allah terhadap apa yang diperintahkan-Nya kepada mereka dan selalu mengerjakan apa yang diperintahkan"(Qs. At-Tahrim: 6)".

Menurut M. Quraish Shihab (2004:326) juga menjelaskan berkaitan dengan surat Ah Tahrim ayat 6 tersebut. Yaitu memberikan makna pada "memelihara keluarga" yang meliputi, istri, anak-anak dan seluruh yang ada di bawah tanggung jawab suami, dengan membimbing dan mendidik mereka agar semuanya terhindar dari api neraka. Dan lagi Ahmad Mushthafa Al Maraghi (1989:261-262) juga memberikan penafsirannya berupa, mengajarkan kepada keluarga akan perbuatan yang dapat menjaga diri melalui nasehat dan pengajaran. Yang dimaksud al-ahl (keluarga), disini mencakup istri, anak-anak, budak baik laki/perempuan.

Sedangkan menurut Hamka (1999:7507) ayat ini memberikan anjuran untuk memberikan pendidikan dan pengetahuan mengenai kebaikan terhadap diri dan keluarga. Beriman saja tidaklah cukup, iman mestilah dipelihara baik untuk keselamatan diri dan rumah tangga. Sebab dari rumah tangga itulah dimulai menanamkan iman dan memupuk Islam. Karena dari rumah tangga itulah akan terbentuk umat. Dan dalam umat itulah akan tegak masyarakat Islam. Masyarakat Islam adalah suatu masyarakat yang bersamaan pandangan hidup, bersamaan penilaian terhadap alam.

Menurut tafsir ayat-ayat pendidikan (tafsir al-ayat AlTarbawih), Abuddin Nata (2002:198) memberikan penjelasan, bahwa "quuanfusakum" berarti membuat penghalang datangnya siksaan api neraka, dengan cara menjauhkan perbuatan maksiat, memperkuat diri agar tidak mengikuti hawa nafsu, dan senantiasa taat menjalankan perintah 
Allah SWT. Sedangkan "wa ahlikum" adalah keluarga yang terdiri dari istri, anak, pembantu, dan budak, diperintahkan untuk menjaganya dengan cara memberikan bimbingan, nasehat dan pendidikan kepada mereka.

\section{Jenis Pola Asuh Orangtua}

$\begin{array}{clc}\text { Setiap } & \text { orangtua selalu } \\ \text { menginginkan } & \text { yang terbaik bagi }\end{array}$
anak-anak mereka. Hal inilah kemudian mendorong orangtua untuk memiliki pola asuh tertentu dalam mengasuh anak-anak mereka baik sadar maupun tidak. Pola Asuh adalah gambaran yang dipakai oleh orang tua untuk mengasuh (merawat, menjaga atau mendidik) anak (Singgih D. Gunarsa, 1991: 108-109).

\section{Sedangkkan menurut Chabib}

Thoha

(1996:109) yang mengemukakan bahwa pola asuh orang tua adalah suatu cara terbaik yang dapat ditempuh orang tua dalam mendidik anak sebagai perwujudan dari rasa tanggung jawab kepada anak. Peran keluarga menjadi penting untuk mendidik anak baik dalam sudut tinjauan agama, tinjauan sosial kemasyarakatan maupun tinjauan individu. Jika pendidikan keluarga dapat berlangsung dengan baik maka mampu menumbuhkan perkembangan kepribadian anak menjadi manusia dewasa yang memiliki sikap positif terhadap agama, kepribadian yang kuat dan mandiri, potensi jasmani dan rohani serta intelektual yang berkembang secara optimal. Sehingga perilaku-perilaku pola asuh ini kemudian di teliti dan muncullah beberapa teori untuk menyimpulkan pola-pola pengasuhan yang berkembang. Berikut empat tipe pola asuh yang dikembangkan oleh Baumrind dalam Agus Dariyono (2004:97).

1. Pola asuh demokratis

Pola asuh Demokratis adalah pola asuh yang memprioritaskan kepentingan anak, akan tetapi tidak ragu-ragu mengendalikan mereka. Orang tua dengan pola asuh ini bersikap rasional, selalu mendasari tindakannya pada rasio atau pemikiran-pemikiran. Orang tua tipe ini juga bersikap realistis terhadap kemampuan anak, tidak berharap yang berlebihan yang melampaui kemampuan anak.

Orang tua tipe ini juga memberikan kebebasan kepada anak untuk memilih dan melakukan suatu 
tindakan, dan pendekatannya kepada anak bersifat hangat. Sehingga hasil dari pola asuh ini menjadikan karakteristik anak yang mandiri, dapat mengontrol diri, mempunyai hubungan baik dengan teman, mampu menghadapi stress, mempunyai minat terhadap hal-hal baru, dan koperatif terhadap orang-orang lain.

2. Pola asuh otoriter (parent oriented)

Pola asuh otoriter sebaliknya cenderung menetapkan standar yang mutlak harus dituruti, biasanya dibarengi dengan ancaman-ancaman. Misalnya, kalau tidak mau makan, maka tidak akan diajak bicara. Orang tua tipe ini juga cenderung memaksa, memerintah, menghukum. Apabila anak tidak mau melakukan apa yang dikatakan oleh orang tua, maka orang tua tipe ini tidak segan menghukum anak. Orang tua tipe ini juga tidak mengenal kompromi, dan dalam komunikasi biasanya bersifat satu arah. Orang tua tipe ini tidak memerlukan umpan balik dari anaknya untuk mengerti mengenai anaknya. Sehingga pola asuh ini akan menghasilkan karakteristik anak yang penakut, pendiam, tertutup, tidak berinisiatif, gemar menentang, suka melanggar norma, berkepribadian lemah, cemas dan menarik diri, pemalu dan tidak percaya diri untuk mencoba hal yang baru.

3. Pola asuh permisif

Sifat pola asuh ini children centered yakni segalaaturan dan ketetapan keluarga di tangan anak. Pola asuh permisif atau pemanja biasanya orangtua memberikan pengawasan yang sangat longgar memberikan kesempatan pada anaknya untuk melakukan sesuatu tanpa pengawasan yang cukup darinya. Mereka cenderung tidak menegur atau memperingatkan anak apabila anak sedang dalam bahaya, dan sangat sedikit bimbingan yang diberikan oleh mereka. Namun orang tua tipe ini biasanya bersifat hangat, sehingga seringkali disukai oleh anak. Sehingga pola asuh permisif akan menghasilkan karakteristik anak-anak yang impulsive, agresif, tidak patuh, manja, kurang mandiri, mau menang sendiri, kurang percaya diri, dan kurang matang secara sosial.

4. Pola asuh penelantar.

Tipe Penelantar. Orang tua tipe ini pada umumnya memberikan waktu dan biaya yang sangat minim pada anak-anaknya. Waktu mereka banyak 
digunakan untuk keperluan pribadi mereka, seperti bekerja, dan juga kadangkala biayapun dihemat-hemat untuk anak mereka. Termasuk dalam tipe ini adalah perilaku penelantar secara fisik dan psikis pada ibu yang depresi. Ibu yang depresi pada umumnya tidak mampu memberikan perhatian fisik maupun psikis pada anak-anaknya pola asuh penelantar akan menghasilkan karakteristik anak-anak yang moody, impulsive, agresif, kurang bertanggung jawab, tidak mau mengalah, Self Esteem (harga diri) yang rendah, sering bolos, dan bermasalah dengan teman.

Dari beberapa pola asuh yang sudah dijelaskan di atas dapat kita simpulkan bahwa setiap pola asuh tersebut pasti memilik sisi positif dan sisi negatif, ibarat mata uang koin maka disetap dari sisi dua mata uang tersebut memiliki makna tersendiri. Maka dari keempat model pengasuhan diatas, pola asuh demokratislah yang paling baik. Karena pola asuh ini menempatkan anak dan orangtua sejajar. Tidak ada hak anak yang dilanggar juga hak orangtua yang dilanggar; kewajiban anak dan orangtua sama-sama dituntut dalam pola asuh demokratis ini.

\section{Penutup}

Setiap anak memiliki keperibadian yang sangat unik, sehingga tinggal orangtua mengelola dan membentuk potensi tersebut berdasarkan prinsip perkembangan anak, maka pendidikan anak usia dini harus berlandaskan pada kebutuhan anak, yang disesuaikan dengan nilai-nilai yang dianut lingkungan di sekitarnya, dalam hal ini orangtua menjadi penggerak utama yang sangat berpengaruh dalam mengoptimalkan potensi anak dengan cara menstimulus dan menyediakan berbagai fasilitas yang dibutuhkan anak.

\section{Daftar Pustaka}

Al-Maraghi, Mushtafa , Ahmad. 1989, Terjemah. TafsirAl-Maraghi, (28), Semarang: CV. Toha Putra.

Azra, Azyumardi. 1990, Pendidikan Islam; Tradisi dan Modernisasi Menuju Millenium Baru, Jakarta: Logos Wacana Ilmu.

Conny R. Semiawan. 1999/2000. Perkembangan dan Belajar Peserta Didik. Jakarta: Departemen Pendidikan dan Kebudayaan Direktorat Jenderal Pendidikan Tinggi.

Dariyo, Agoes. 2004. Psikologi Perkembangan Remaja. Jakarta: Ghalia Indonesia.

Depdiknas,2002, Kurikulum Hasil belajar Pendidikan Anak Usia Dini, (Jakarta: Depdiknas). 
Gardner, H. 1993, Frame of Mind: the Theory of Multiple Intelligences, New York: Basic Books.

Gunarsa, Singgih D. 1995. Psikologi Perkembangan. Jakarta: BPK Gunung Mulia.

HAMKA. 1999, Tafsir Al-Azhar, Singapura: Pustaka Nasional.

Hasenstab. 1982, Comprehensive Intervention with Hearing-Impaired Infants and Preschool Children, London: An Aspen Publication.

Hasenstab. 1982, Comprehensive Intervention with Hearing-Impaired Infants and Preschool Children, London: An Aspen Publication.

Hurlock, Elizabeth B. 1998. Psikologi Perkembangan, terj. Istiwidiyanti dan Soedjarwo. Jakarta: Erlangga

Kartini Kartono. 2007. Psikologi Anak (Psikologi Perkembangan). Bandung: CV. Mandar Maju.

Langgulung, Hasan. 1992, Asas-Asas Pendidikan Islam, Jakarta: Pustaka Al Husna.

Mulyani Sumantri dan Nana Syaodih. 2006. Perkembangan Peserta Didik. Jakarta: Universitas Terbuka.

Munandar, Utami. 1999, Kreativitas dan Keberbakatan. Jakarta: PT. Gramedia Pustaka Utama.

Nata, Abuddin. 2002, Tafsir Ayat-Ayat Pendidikan (Tafsir al ayat
Al-Tarbawiy), Jakarata: PT. Raja Grafindo Persada.

Papalia, Diane E, Etc. 2008. Human Development

(Psikologi Perkembangan, terjemahan A. K. Anwar). Jakarta: Kencana Prenada Media Gru

Santrock W John. 1995. Life Span Development, Jakarta: PT Erlangga, 1995.

Shihab, M. Qurasaish. 2002, Tafsir Al Misbah pesan, kesandan keserasian $A l$ Quran Vol.10 Jakarta: Lentera hati.

Shihab, Quraish. 2004, Tafsir Al-Mishbah, Pesan, kesan dan keserasian Al-Qur'an, Jakarta: Lentera Hati, 2004.

Sukmadinata, Nana Syaodih. 2004. Landasan Psikologi Proses Pendidikan, Bandung : Remaja Rosdakarya.

Syekh Faishal bin Abdul Aziz Ali Mubarak Qodhil Jaufi, Bustanul Ahbar Muhktasyar Nailul Authar, terj. Mu'ammal Hamidi dkk, (Surabaya: PT. Bina Ilmu, 2005).

Tafsir, Ahmad. 2008, Ilmu Pendidikan dalam Perspektif Islam,Bandung: PT Remaja Rosda Karya.

Thoha, chabib. 1996. Kapita Selekta Pendidikan Islam, Yogyakarta : Pustaka pelajar (IKAPI) 